ing ordinary least squares regression equation: predicted \% uptake of diphtheria immunisation = 101-0.641 (\% households with dependent children with $>1$ person per room). This implies that eliminating overcrowding in such households could lead to an immunisation uptake rate of $101 \%$, but any rate greater than $100 \%$ is meaningless.

The reason for these problems is that ordinary least squares regression is a generalised linear model which assumes that the dependent variable can have values unrestricted in size, measured continuously, and distributed according to the normal probability distribution. Immunisation uptake percentages do not conform to these conditions. They are closed numbers, based on the ratio of two discrete counts, in this case the number of children born in 1983 and immunised agains diphtheria by the end of 1985 divided by the total number of live births in 1983. This is an example of a binomially distributed variable, and the appropriate form of the generalised linear model is a binary logit regression, which requires a weighted leas squares or maximum likelihood estimation procedure.

Using the generalised linear interactive modelling package ${ }^{l}$ we re-estimated the above equation as: $\log _{\mathrm{e}}$ (uptake of diphtheria immunisation/(100$\%$ uptake of diphtheria immunisation) $)=3 \cdot 004-$ 0.04864 ( $\%$ households with dependent children with $>1$ person per room). The left hand side is the logit transformation, which ensures that predicted uptake percentages can neither be negative nor exceed $100 \%$, irrespective of any value an explanatory variable may take. Putting extreme values of $0 \%$ and then $100 \%$ overcrowding into this equation, and noting that 3.004 is a natural logarithmic value, the maximum and minimum predicted uptake rates are $95 \cdot 28 \%$ and $13 \cdot 47 \%$.

M L SENIOR SUZANNE J NEW

Department of Geography,

University of Salford,

Salford M5 4WT

Department of Geography,

University of Lancaster,

Lancaster LA1 4YB

1 Payne CD, ed. The GLIM system: release 3.77 manual. Oxford: NAG Lid, 1986.

\section{Surgical closure of the back lesion in open neural tube defects}

We thank Dr A Norman Guthkelch for his comments (2 July, p 67) on our short report (21 May, p 1441).

It must be borne in mind that the data on patients that we presented are from the group with the worst prognosis for open neural tube defects, in which the mortality is recognised to be highest. Dr Guthkelch quotes from several heterogeneous series and this makes comparison with our data difficult. Among the series he quotes about half the patients were in the worst prognosis group, whereas among those born in Northern Ireland about three quarters of babies with open neural tube defects have a neurological level above L2. Although a breakdown of this most severely affected subset of open neural tube defects is not readily available from North American centres, it is possible that the profile of disease in these patients is less severe than in Northern Ireland, where just over a third have a neurological level at or above T10. There is no doubt that in the series from North America that Dr Guthkelch reported survival at 1 year seems to be higher than in the United Kingdom. The most relevant and up to date review from the "Celtic fringe" of United Kingdom by Carstairs and Cole quotes data on mortality not unlike our own. 'Perhaps the factor that Dr Guthkelch alludes to as the cause of ou excess mortality is that we encounter a more severe form of spina bifida than similar centres in North America.

We would have welcomed his constructive comment on the significance of the relative incidence in our index and control groups of complications which were likely to be independent of treatment other than closure of the back lesion. I would seem that despite the emerging evidence to the contrary (including that of Charney et al, which he quotes ${ }^{2}$ ) Dr Guthkelch still has a conviction that early closure is the only correct treatment for these unfortunate children. We wonder why 20 years ago he never performed the prospective controlled trial of closure versus non-closure that he now so earnestly requests?

G T DEANS

V E BOSTON

Royal Belfast Hospital for Sick Children,

Belfast BT12 6BE

1 Carstairs V, Cole S. Spina bifida and anencephaly in Scotland. $\mathrm{Br}$ Med f 1984;298:1182-4

2 Charnley EB, Sutton LN, Bruce DA, Schut LB. Myelomeningocoele newborn management: time for parental decision. coele newborn management: time
$Z$ Kinderchir 1983;38(suppl 2): $90-3$.

\section{Obstructive uropathy}

Owing to overenthusiastic editing of my letter (2 July, p 68) the main point that I wanted to make was obscured.

Ultrasound examination is not good at detecting dilatation of the pelvicaliceal system because it is subject to false negative and false positive results and because it shows only anatomy, and not physiology. Despite this it has been accepted enthusiastically, probably because it is painless, easy, and relatively fast.

I think that the problem is a philosphical one and stems from three false propositions-that it is possible to exclude a diagnosis (in this case acute obstruction), that obstruction and dilatation of the urinary tract are equivalent, and that any mature imaging technique (such as ultrasound examination) may be used in the investigation of any problem with a chance of success equal to that with any other mature imaging technique.

If the advice given by Dr S Mindel (26 March, p 929) was followed it would be easy for ultrasound studies to become merely routine examinations that contribute nothing to the diagnosis.

Department of Radiology,

City Hospital,

Nottingham NG10 4FG

PETER DAVIES

\section{Presenting features in Wegener's granulomatosis}

We are in broad agreement with the conclusion of Dr M G Ridley and coworkers (30 July, p 352), but we note that both their patients had fever, raised erythrocyte sedimentation rate, pulmonary infiltrates, and haemoptysis. In the differential diagnosis of Wegener's granulomatosis it is not uncommon to include secondary malignancy, but these features can also easily be mistaken for pulmonary tuberculosis, as in our case.

A 59 year old painter with a two month history of malaise, tiredness, loss of weight, and pulmonary lesions was referred by his general practitioner to the chest clinic. He was feverish, erythrocyte sedimentation rate was $104 \mathrm{~mm}$ in the first hour, haemoglobin was $112 \mathrm{~g} / \mathrm{l}$, and a chest radiograph showed pulmonary infiltrates not untypical of pulmonary tuberculosis. His sputum was negative for acid fast bacilli and he started taking triple antituberculous therapy (rifampicin, isoniazide, and pyrizinamide). Ten days later he was admitted with a swinging temperature, maculopapular rash all over his body, arthralgia mainly affecting the small joints of the hands, herpes labialis, and severe bout of haemoptysis. He also developed acute renal failure, the plasma urea and creatinine concentrations being $44.5 \mathrm{mmol} / \mathrm{l}$ and $1129 \mu \mathrm{mol} / \mathrm{l}$ respectively. He was then referred to the renal unit.

On admission he was extremely poorly with a temperature of $38.2^{\circ} \mathrm{C}$, erythrocyte sedimentation rate of $115 \mathrm{~mm}$ in the first hour, and $\mathrm{C}$ reactive protein concentration of $76.8 \mathrm{mg} / \mathrm{l}$ (normal $<10$ $\mathrm{mg} / \mathrm{l}$ ). Urine analysis showed both protein and blood $(++)$, and microscopy confirmed dysmorphic red cells. Immunochemical tests showed no autoantibodies, normal immunoglobulins, normal C3, and slightly diminished C4. Fibreoptic bronchoscopy showed no lesions, and bloodstained lavage fluid failed to show acid fast bacilli. A biopsy specimen from the granulomatous lesion on the tip of his tongue showed vasculitis, and renal biopsy confirmed rapidly progressive glomerulonephritis with crescents and vasculitis. He was started on prednisolone and cyclophosphamide and received plasma exchange treatment on four consecutive days. His lung lesions cleared but the renal function did not improve and he remained well on regular haemodialysis. Subsequently the titre of antibody to neutrophil cytoplasmic antigen was reported to be significantly raised. (Dr C M Lockwood, Department of Immunology, Hammersmith Hospital, London.)

This case history, along with the two described by Dr M G Ridley and coworkers, illustrates the problems experienced in diagnosing Wegener's granulomatosis. The availability of the assay for neutrophil cytoplasmic antibody ${ }^{1}$ may possibly help in the early diagnosis of systemic vasculitis. Unfortunately, our patient developed endstage renal failure. There has been renewed interest in hydrocarbon exposure and glomerulonephritis, ${ }^{2-4}$ and, although we have no proof, we speculate that prolonged exposure to hydrocarbons in his job as a painter was a contributory factor in his illness.

M YAQOOB R AHMAD

Royal Liverpool Hospital

Liverpool L7 8XP

1 Savage COS, Winearls CG, Jones PD, Marshall PD, Lockwood CM. Prospective study of radio immunoassay for antibodies against neutrophil cytoplasma in diagnosis of systemic vasculitis. Lancet 1987; i:1389-93.

2 Finn R, Fennerty AG, Ahmad R. Hydrocarbon exposure and glomerulonephritis. Clin Nephrol 1980;14:173-5.

3 Bell GM, Gordon ACH, Lee P, et al. Proliferative glomerulonephritis and exposure to organic solvents. Nephron 1985;40: nephris

4 Daniell WE, Couser WG, Rosenstock L. Occupational solvent exposure and glomerulonephritis. JAMA 1988;259:2280-3.

Dr M G Ridley and colleagues drew attention to the problems of diagnosing systemic vasculitic conditions such as Wegener's granulomatosis and pointed out that the clinical presentation of Wegener's granulomatosis and histological appearances of the lesions are often misleading.

The recent description of antibodies to neutrophil cytoplasmic antigens has provided a reliable diagnostic marker for many cases of Wegener's granulomatosis. ${ }^{12}$ These antibodies are directed against a membrane associated protein (unpublished observations), possibly in azurophilic granules, ${ }^{3}$ but their pathogenetic importance is unclear. An international working party on antibodies to neutrophil cytoplasmic antigens has been formed ${ }^{4}$ and will supply positive control serum for laboratories wishing to offer this diagnostic service.

Department of Pathology,

RAJESH KHARBANDA

University Medical Schoo

Edinburgh EH8 9AG 